\title{
Investigation of ecological potentials of the Eger Model Region by GIS methods
}

\author{
ANNA ŐRSI ${ }^{1}$ and ÁdÁm KERTÉSZ ${ }^{1}$
}

\begin{abstract}
Various parts of a landscape unit or region can be used for multiple purposes. Before the collectivisation of agricultural fields in the 1960s, the use of the land was more or less in accordance with the given natural conditions. After collectivisation, huge plots were created, neglecting the features of the capability of the area. The map of ecological potential types shows favourable and unfavourable conditions for agricultural and forestry use, i.e. it indicates which parts of the region offer the best ecological conditions for arable cultivation, viticulture, fruit production, cultivation of meadows and pasture, just to mention a few. A capability assessment using GIS is being carried out for the total area of the Eger region. The database used for the capability analysis contains the Corine 1990 and 2006 data, soil maps and the National Gully Cadastre. The map is compared with present-day land use and the discrepancies between landscape capability and present land use are identified. Suggestions are made to optimise land use according to the capability map. Alterations since the change of the regime in 1989 have been determined and analysed from the aspect of suitability, as well.
\end{abstract}

Keywords: map of ecological potentials, ecological potential types (ecopottyp), land use, capability assessment, GIS

\section{Introduction}

Landscape science, landscape ecology deals with the interactions between the abiotic and biotic spheres and the human society. It studies the causes and the consequences of differences and heterogeneity among the landscapes at different scales, thus seeking to establish a scientific foundation for practical applications, including landscape planning and landscape management. The discipline of landscape ecology was the first applied science in the field of physical geography.

\footnotetext{
${ }^{1}$ Geographical Institute, Research Centre for Astronomy and Earth Sciences of the HAS, H-1112 Budaörsi út 45. Budapest, Hungary. E-mails: orsi.anna@csfk.mta.hu, kertesz.adam@csfk.mta.hu
} 
The demand for applied landscape studies and landscape ecology emerged in the middle of the last century all over the world. Landscape planning, landscape management, landscape prognosis, landscape protection and nature conservation stood in the focus of research of the Russian and German schools of landscape science. Landscape ecology was flourishing in the 1960s and 1970s in Europe, especially in Germany, mainly in the German Democratic Republic, e.g. Troll, C. (1968, 1970), Leser, H. (1976) and in the Soviet Union (e.g. Solntsev, N.A. 1968; Sochava, V.B. 1971).

Applied landscape research was carried out in many other countries of Europe. Ecodynamical mapping was the main activity of the French school (Tricart, J. 1976; Journaux, A. 1975, 1981). The Anglo-Saxon school was very much practice-oriented, focusing, first of all, on land evaluation (HowEs, C.K. 1980; Naveh, Z. And Lieberman, A.S. 1984).

The importance of applied landscape science increased significantly in the second half of the last century, however, that time the centre of landscape studies shifted from Europe to the United States. This shift can be verified by the appearance of major publications (Forman, R.T.T. and Gordon, M. 1986; Naveh, Z. and Lieberman, A.S. 1994; Naveh, Z. 2000).

In the 1960s, Hungarian physical geographers also started to focus on applied geography and landscape ecology. Land evaluation, land capability assessment aimed at exploring and evaluating natural conditions favourable or unfavourable for various branches of the economy. Various landscapes dispose of different features providing utilization options, i.e. landscapes have a potential to meet various requirements of the society. Landscape potential is the basis of landscape evaluation. According to their potentials, landscapes can be classified into different types.

In the 1960s, Marosi, S. and SziLÁrd, J. (1963b) evaluated the area of the Somogy Hills from the point of view of agricultural use. They classified the landscapes according to the natural conditions (geology, topography, climate, hydrology and soils) provided for agriculture. These territorial units were defined as the "spatial unit types of natural conditions for farming", landscape potential types or ecological potential types, the abbreviation is "ecopottyp". The same concept is applied in this paper.

Before the collectivization of private farms in the 1960s, farming was more or less in accordance with the natural conditions. As a consequence of collectivization, huge plots were created in order to facilitate large-scale farming.

It has to be emphasized that the ecological potential types are considered to be homogeneous in terms of natural conditions, i.e. the natural conditions predestine the optimal use of a given area. Generally, areas aren't used in an optimal way, therefore the question arises whether this situation can be justified by economic or political considerations. In many cases, an area with 
heterogeneous conditions is used homogeneously. Landscape ecologists suggest the adaptation to the heterogeneous, diverse natural conditions in order to make the management of the area more environment-friendly and thus better adapted to natural conditions.

According to Marosi, S. and SzILÁrd, J. (1963a), landscape scientists should consider which landscape forming factors are the most relevant for the identification of the ecological potential types. Among the landscape forming factors, topography plays a crucial role by affecting other landscape forming factors (soils, vegetation, hydrological conditions etc.). Even the variety of the meso- and microclimate is strongly influenced by the heterogeneity of topography.

Contemporary Hungarian papers also deal with various aspects of the topic. Lóczy, D. (2002) published a textbook on landscape and land evaluation, surveying international and national assessment methods. Recent trends of landscape assessment are reviewed by HervaI, A. (2010). Landscapes with various natural conditions are evaluated by Csorba, P. and Szabó, Sz. (2008) applying the method of landscape metrics. BArczI, A. et al. (2008) published a paper on landscape and agri-environmental assessment.

The objective of this paper is to present the map of the ecological potential types and to compare it with the map of current land use in order to explore the differences and the discrepancies between them and finally to propose optimal land use. Another important aim is to investigate whether land use changes after the change of the regime, i.e. after the reprivatisation process led to a healthier land use and plot structure corresponding to the natural endowments.

\section{Study area}

The study area contains the administrative area of the 23 settlements of the Agria InnoRegio. The Agria InnoRegio itself is not an administrative unit, its boundaries were established for the TÁMOP 4.2.2/A project² (Figure 1).

The topography of the study area is very varied, extending from the Northern part of the Great Hungarian Plain to the Southern part of the North Hungarian Mountains, including lowlands, hilly countries and mountains (111-928 $\mathrm{m}$ a.s.l.). The greatest part of the area, extending to the South and South-East from the city of Eger is a piedmont plain, a glacis dissected by valleys. In spite of being dissected, the overwhelming part of that gently sloping

\footnotetext{
2 "Complex analysis of the potential use of natural resources considering the effects of climatic change in order to develop an energetically sustainable model region under German-Hungarian cooperation."
} 


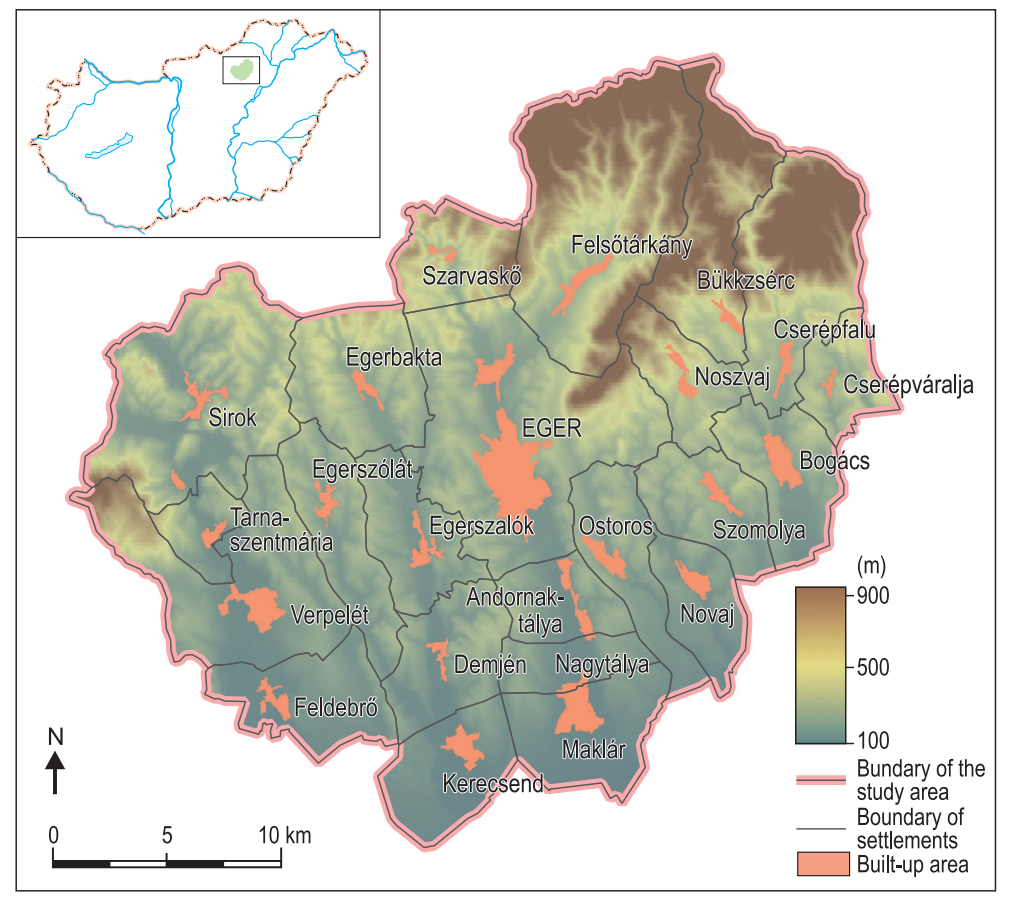

Fig 1. The location and the terrain of the study area

plain is homogeneous, there are large uniform fields between the valleys offering ideal conditions for agricultural use. North of Eger hilly and mountain ridges are characteristic with moderate or steep slopes. Soil parent rocks are Oligocene schlier, marl and sand in the northern part, Lower Miocene rhyolite tuff and loess in the South and Pliocene clayey-loamy sediments in the South-West.

The climate is moderately warm - moderately dry except the northern part which is cool. The number of sunshine hours exceeds 1850 a year. The mean annual temperature is around $8-10{ }^{\circ} \mathrm{C}$, the annual rainfall is about 600 $\mathrm{mm}$. Luvisols dominate in the foreground of the mountains, Cambisols and Chernozems are characteristic in the areas close to the Great Hungarian Plain, Fluvisols along the watercourses. The area is intensively cultivated, vineyards, croplands, pastures and orchards are typical on the not forested parts of the study site. The forests in the mountains are Quercetum petraeae-cerris forests. The Quercetum petraeae-cerris forest is in many cases replaced by acacia (Robinia pseudoacacia) and pasture. Querceto petraeae Carpinetum forests can be found at the bottom of steep valleys (DövÉNYI, Z. ed. 2010). 


\section{Data and methods}

The methods applied in this paper are based on the above mentioned papers of Marosi, S. and SzILÁrd, J. (1963a,b). The innovativeness of our approach is the application of geoinformatics, i.e. exploiting the possibilities offered by GIS. In the last century ecological potential maps were prepared manually and topographic maps were used as a basis of map compilation. The manual method did not allow for putting a very detailed and precise map together.

The calculations presented below were performed by the ArcMap software. The following data sources were used: the Corine Land Cover Database (BütTNeR, G. et al. 2002) for the years 1990 and 2006, SRTM data (RAbus, B., et al. 2003), the AGROTOPO database (RISSAC, 1991) and the National Gully Cadastre (MAri, L. and MAtTánYI, Zs. 2002; Kertész, Á. et al. 2012).

The methodological steps are as follows:

1. Slope gradient and slope aspect maps were derived from the digital terrain model.

2. A gully density map was prepared using the data of the National Gully Cadastre.

3. The valley network was determined by calculating the flow direction and flow accumulation from the terrain model.

4. Fluvisols and Vertisols were selected from the AGROTOPO database.

The following categories were distinguished on the map of ecological potentials:

1. Areas suitable for arable use without soil conservation measures,

- slope gradient $0-5 \%$.

2. Areas suitable for arable use applying soil conservation measures,

- slope gradient 5-17\% and northern exposure.

3. Areas suitable for vineyards and orchards,

- slope gradient $12-25 \%$ and southern exposure.

4. Areas suitable for forestry,

- slope gradient above $25 \%$,

- slope gradient $17-25 \%$ and northern exposure,

- areas dissected by gullies,

- areas above $300 \mathrm{~m}$ elevation a.s.l.

5. Areas suitable for meadow and pasture,

- areas covered by Vertisol and Fluvisol.

6. Wetlands on valley bottoms.

7. Settlements were excluded.

In the following, we intend to find answers to the question how much of current land use (the most recent data reflect the 2006 status) is in accord- 
ance with the natural conditions, with the ecological potential. The second question is whether land use has been moving since the change of regime land use towards the ecological potential of the area, i.e. to the optimal state, or moving away from it. We compared the map of ecological potentials with the Corine Land Cover (CLC) databases for the years 1990 and 2006.

The CLC database had to be reclassified according to the categories of the map of ecological potentials. As the Corine database does not distinguish between arable land with or without soil conservation measures, we used six categories: anthropogenic surface, arable land, vineyard and orchard, grassland (meadow, pasture, grassland), forest, scrubland and wetland (Figure 2).

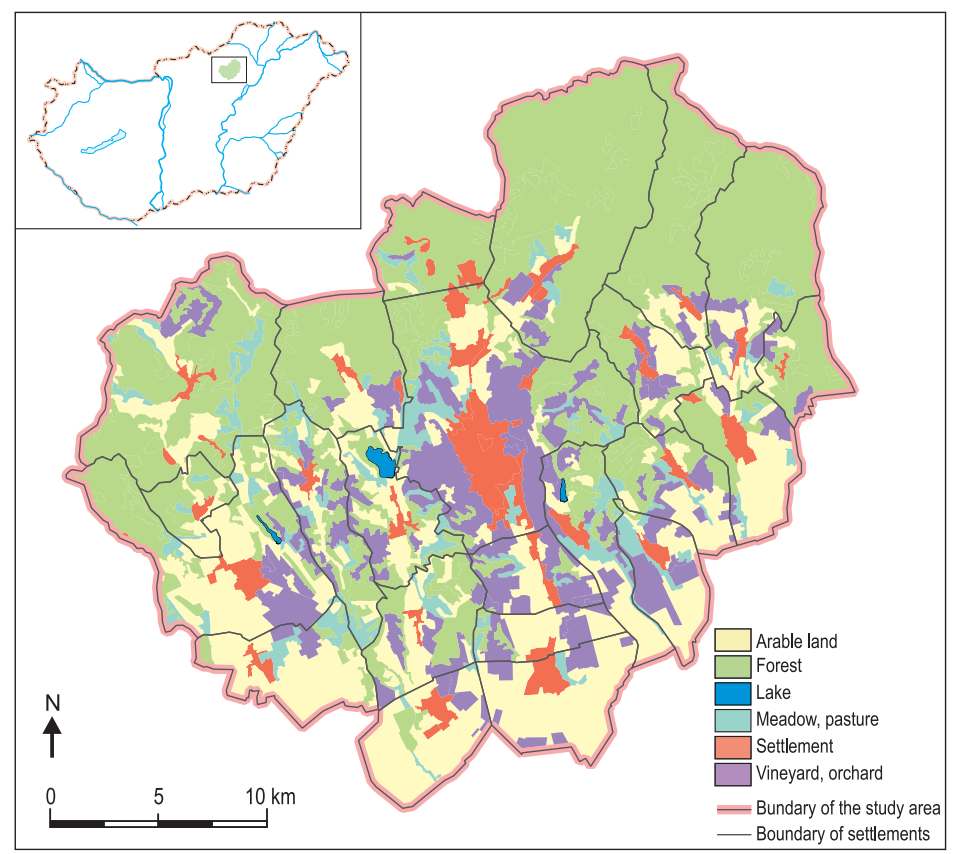

Fig. 2. Simplified land use map of the Eger Model Region

\section{Results}

According to the map of ecological potentials the flattest, southern part of the study area is the most suitable for arable use without applying soil conservation measures (Figure 3). These areas continue further northwards along the valley bottoms on the alluvial plains. The northern territories, i.e. the Bükk Mountains are suitable for forestry use. The areas located between these two are characterised by medium steep slopes (5-25\%). Among them, the slopes 


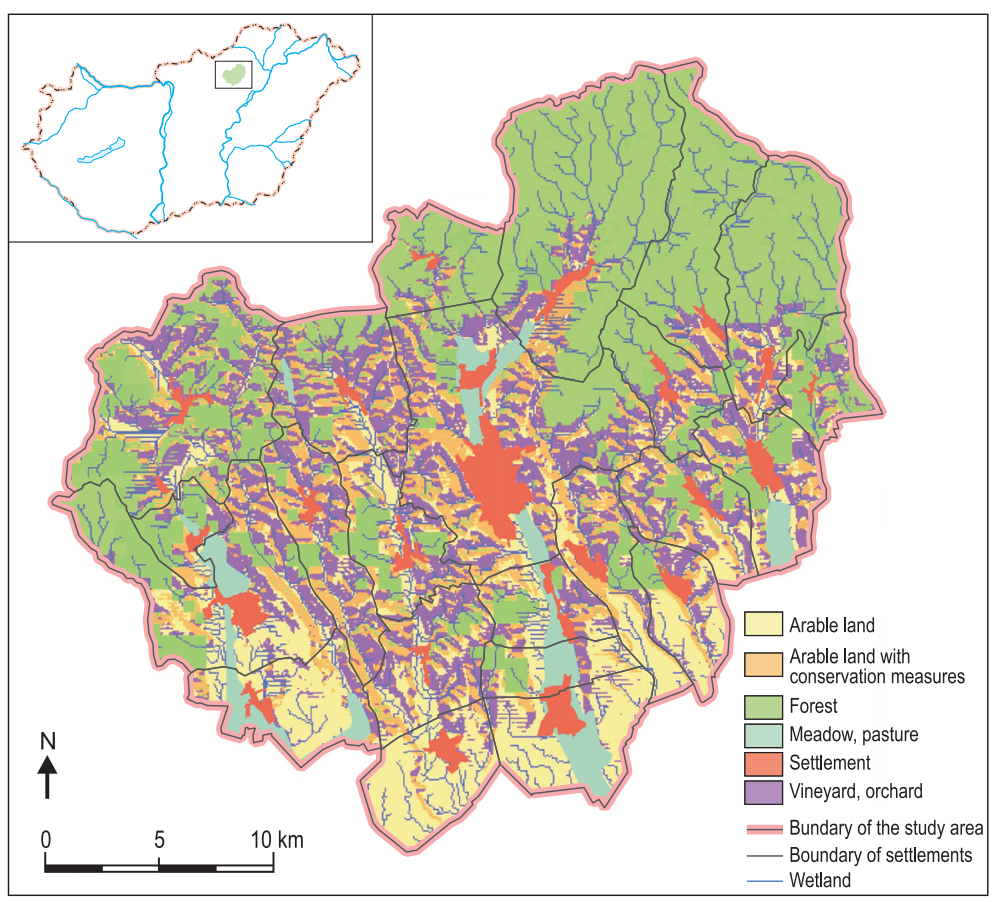

Fig. 3. The map of ecological potentials of the Eger Model Region

exposed to the South are proposed to be utilized as vineyards, those with northern exposure are proposed to be used as arable land with soil conservation measures. They are interrupted by areas suggested for afforestation. They cannot be recommended for agricultural cultivation due to their high dissection and vulnerability to soil erosion.

Wetlands are located in the valleys of the hills and mountains and on lowland, as well. Based on the map of ecological potentials, meadows and pastures should only be located alongside the larger watercourses.

Comparing the map of ecological potentials with the Corine Land Cover databases for the years 1990 and 2006, there is very little difference between the two maps (only a few percent). The difference is so small that it may be due to the differing resolution of the databases. The scale of the 1990 Corine map is 1:100,000 and that of the 2006 map is 1:50,000. (No 1:50,000 maps for the year 1990 were available.) Because of this discrepancy, only the 2006 data will be taken into consideration in the below analysis.

In $2006,46 \%$ of the area was utilized in accordance with the categories of the ecological potential map. Of course, it cannot be asserted that the re- 
maining $54 \%$ of the land was used and managed totally unsuitably as a given territory may be used for multiple purposes even if the applied use is not the optimal one. On the other hand, economic and political aspects also have to be considered: in many cases, the ecological potential map created by GIS is too detailed, while homogeneous areas may be more suitable for cultivation. In this case, the adverse local circumstances have to be improved by the means of ameliorisation.

Table 1 shows the percentage of each land use category corresponding and not corresponding to the ecological potential. $57 \%$ of the arable land can be found in the areas suitable for arable cultivation, $15 \%$ in areas suitable for vineyards and orchards and $12 \%$ in areas suitable for grassland and pasture. It is not necessarily bad to have arable land in areas suitable for vineyards and orchards if the slope angle is below $17 \%$ and the soil conditions are also favourable.

Table. 1. The relationship between present land use and ecological potential in the Eger Model Region in 2006, \%

\begin{tabular}{c|l|r|r|r|r|r}
\hline \multicolumn{2}{c|}{ Land use } & \multicolumn{5}{c}{ Ecological potential } \\
\hline \multirow{3}{*}{$\begin{array}{l}\text { Corine Land- } \\
\text { Cover 2006 }\end{array}$} & $\begin{array}{c}\text { arable } \\
\text { land }\end{array}$ & $\begin{array}{c}\text { vineyard- } \\
\text { orchard }\end{array}$ & pasture & forest & wetland \\
\cline { 2 - 7 } & arable land & 57.49 & 14.52 & 11.85 & 5.38 & 10.76 \\
& vineyard-orchard & 47.54 & 31.52 & 1.38 & 14.40 & 5.60 \\
& pasture & 34.57 & 26.15 & 2.34 & 24.37 & 12.57 \\
& forest & 15.52 & 14.29 & 0.18 & 62.74 & 7.27 \\
\hline
\end{tabular}

Nearly $50 \%$ of the vineyards and orchards are located in areas suitable for arable cultivation, namely the slopes with northern slope aspect, whereas vineyards are mostly larger connected fields. Another $14 \%$ of the vineyards and orchards are located in the areas suitable for forestry. It is very inconvenient because the risk of soil erosion is high if the area is too steep or if it is already dissected by gullies.

It is surprising that $35 \%$ of the meadows and pastures is located on areas suitable for arable cultivation and only $2 \%$ of the area is suitable for meadows and pastures. It can be explained by the scale of the soil map (1: 100,000) which is not detailed enough and because of that, Vertisols and Fluvisols covering the alluvia of small streams are not shown on the soil map. In reality, meadows and pastures are on the alluvia of smaller streams, but the patches of them are too small to be represented on the soil map which was the basis of the delineation of the areas suitable for meadows and pastures.

Almost two-thirds of the forests are in the areas suitable for forestry use, which is the largest coincidence comparing present land use with the ecological potential. The wetlands which were identified on the valley bottoms are too narrow to be represented in the 1:50,000 scale Corine Database. 


\section{Conclusions}

The GIS method proved to be a very good and very precise tool for the identification of the units of the ecological potential map. The comparison of the ecological potential map with present land use brought very interesting results (Figure 4).

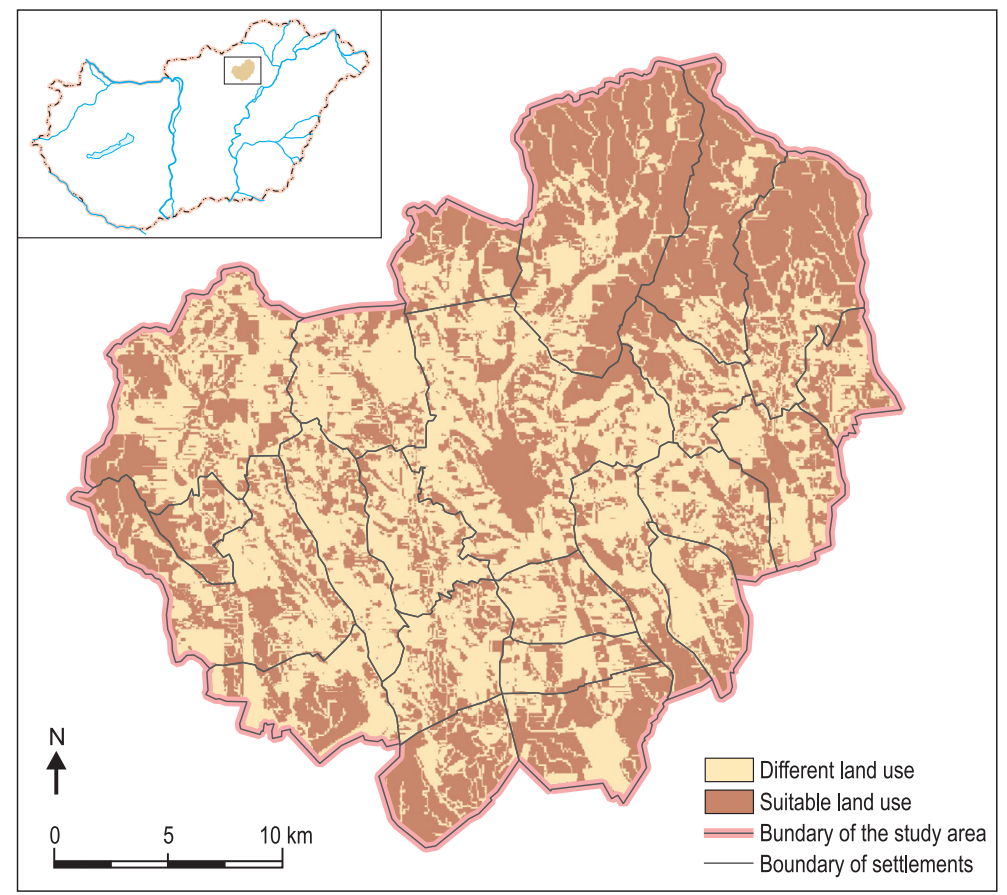

Fig. 4. Map of the areas with the type of land use corresponding to the ecological potential where present land use is different from the ecological potential in the Eger Model Region

The highest coincidence between ecological potential and land cover was found in the case of forests and arable lands. The coincidence is the lowest in the case of grasslands because of the scale of the available soil map. A more detailed soil map will be necessary to improve the present result concerning grasslands. It should be discussed whether land use changes are necessary if the land is not used as it would be optimal from the aspect of land capability.

Changes in land use are the most necessary where areas hazardous to erosion are cultivated as vineyards, orchards or arable land. In all other cases, a very thorough analysis of the situation is needed taking both ecological and economic factors into account. 


\section{REFERENCES}

Barczi, A., Csorba, P., Lóczy, D., Mezôsi, G., Konkoly-Gyuró, É., Bardóczi-Székely, E., Csima, P., Kollányi, L., Gergely, E. and Farkas, Sz. 2008. Suggested landscape and agri-environmental assessment. Tájökológiai Lapok 6. (1-2): 77-94.

Csorba, P. and Szabó, Sz. 2009. Tájértékelés tájmetriai módszerekkel (Landscape capability assassment by landscape metrics methods). In: Tiszteletkötet dr. Frisnyák Sándor professzor 75. születésnapjára. Eds. GÁL, A. and HANusz, Á., Nyíregyháza-Szerencs, Nyíregyházi Főiskola Turizmus és Földrajztudományi Intézete - Bocskai István Gimnázium, 61-66.

DövéNYI, Z. ed. 2010. Magyarország kistájainak katasztere (Inventory of Natural Micro-regions of Hungary). Budapest, MTA Földrajztudományi Kutatóintézet, 876 p.

Forman, R.T.T. and Gordon, M. 1986. Landscape Ecology. New York, John Wiley \& Sons, 620 p.

Hervai, A. 2010. A tájértékelés Mo-i tendenciái (Trends of landscape capability assessment). In Tér-Tálentum-Tanítványok 2. Eds. Görcs, N.L. and Pirisi, G., Pécs, Pécsi Tudományegyetem, 107-115.

Howes, C.K. 1980. Value maps. Norwich, Geo Abstracts Ltd., 146 p.

Journaux, A. 1975. Légende pour une carte de l'environment et de sa dynamique. Caen, Publ. L'Université de Caen, 16 p.

Journaux, A. 1981. A környezet dinamizmusának térképezése (Mapping of environmental dynamics). French-Hungarian Geographical Seminar, Budapest, MTA Földrajztudományi Kutatóintézet, 9 p. (Manuscript in Hungarian)

Kertész, Á., JAKAB, G., ÔRsI, A., MAdArász, B. and Szalai, Z. 2012. Magyarország vízmosásainak katasztere (Gully cadastre of Hungary). In Magyar Földtudományi Szakemberek XI. Világtalálkozója: korszerü földtudományi oktatás - versenyképes gazdaság. Eds. MiкA, J. et al., Eger, Eszterházy Károly Főiskola, 85-90.

Leser, H. 1976. Landschaftsökologie. Stuttgart, Ulmer, 432 p.

Lóczy, D. 2002. Tájértékelés, földértékelés (Landscape assessment and land evaluation). Pécs, Dialóg Campus Kiadó, 307 p.

MARI, L. and MATtÁNYI, Zs. 2002. Egységes európai felszínborítási adatbázis: A CORINE Land Cover program (A uniform european land cover database: The CORINE Land Cover Program). Földrajzi Közlemények 50. (1-4): 31-38.

Marosi, S. and SzIlárd, J. 1963a. A természeti földrajzi tájértékelés elvi-módszertani kérdéseiről (Theoretical and methodological issues of landscape evaluation). Földrajzi Értesitó / Hungarian Geographical Bulletin 12. (3): 393-417.

Marosi, S. and Szilárd, J. 1963b. A természeti földrajzi tájértékelés elvi-módszertani kérdései, különös tekintettel a dombsági tájak értékelésére. (Theoretical and methodological issues of landscape evaluation, with special attention to the evaluation of hilly regions of Hungary). Az „MTA Földrajztudományi Kutatócsoport elméleti és módszertani vitaanyagai” sorozat, Budapest, MTA FKCS, 20 p.

NAveH, Z. 2000. What is holistic landscape ecology? A conceptual introduction. Special Issue: Holistic landscape Ecology in Action. Eds. Palang, H., Mander, Ü. and Naveh, Z. Journal of Landscape and Urban Planning 50. 1-6.

Naveh, Z. and Liebermann, A. S. 1984. Landscape Ecology. New York, Springer-Verlag, 356 p.

Naveh, Z. and Liebermann, A.S. 1994. Landscape Ecology. Theory and application. New York, Springer-Verlag, $360 \mathrm{p}$.

Rabus, B., Eineder, M., Roth, A. and Bamler, R. 2003. The shuttle radar topography mission - a new class of digital elevation models acquired by spaceborne radar. -Journal of Photogrammetry and Remote Sensing 57. 241-262. 
RISSAC 1991. Research Institute for Soil Science and Agricultural Chemistry of Hung. Acad. Sci. http://www.mta-taki.hu/hu/osztalyok/gis-labor/agrotopo (2013. 09.01.)

Sochava, V.B. 1971. Geography and Ecology. Soviet Geography 12. 277-291.

Solntsev, N.A. 1968. K teorii prirodnüh komplexov. Vesztnyik MGU. Seria Geografii 3. 14-27.

Tricart, J. 1976. Écodynamique et aménagement. Revue de Géomorphologie Dynamique 25. 19-31.

Troll, C. 1968. Landschaftsökologie. In Pflanzensoziologie und Landschaftsökologie. Ed. TüxeN, R., Den Haag, Dr. Junk Publisher, 1-21.

Troll, C. 1970. Landschaftsökologie als geographisch-synoptische Naturbetrachtung. Ökologische Landschaftsforschung und vergleichende Hochgebirgsforschung. Erdkundliches Wissen 11. 1-13. 


\title{
Geography in Visegrad and Neighbour Countries
}

\section{Regional Socio-Economic Processes in Central and Eastern Europe - 20 Years in Transition and 2 Years in Global Economic Crisis}

\author{
Edited by \\ ÁGNES ERốss and DÁvid KarácsonyI \\ Geographical Research Institute Hungarian Academy of Sciences \\ Budapest, 2011. 169 p.
}

During the last twenty years the erstwhile Soviet bloc countries in Central and Eastern Europe (CEE) have taken distinct routes in post-socialist development, wherein the national trends and internal regional processes proved to be in deep contrast. Responses to the challenges of the global economic crisis also varied, repeatedly brought to the surface long existing regional issues, structural problems and ethnic conflicts. Human geographers are divided in the assessment of the shifts that occurred during the past twenty years and the exchange of experience is vital for finding adequate answers to the new challenges. In order to provide a forum for discussion the Geographical Research Institute

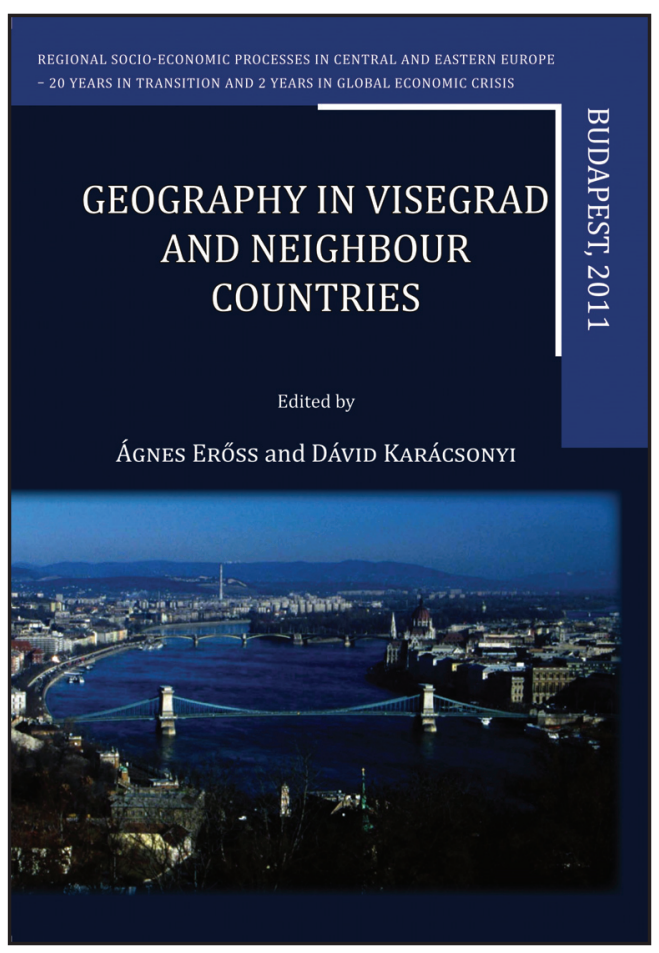
Hungarian Academy of Sciences with the generous support of the International Visegrad Fund Small Grant Programme organized a conference in order to induce the revival of contact between the institutes of geography of Visegrad Countries and their Western and Eastern neighbours. Present volume is a selection of presentations aiming to provide a deeper insight in socio-economic processes and their interpretation from geographical aspects taking place in the broader region of CEE countries.

Price: EUR 10.00

Order: Geographical Institute RCAES HAS Library, H-1112 Budapest, Budaörsi út 45. E-mail: magyar.arpad@csfk.mta.hu 